\title{
Mulching effect on weed control and faba bean (Viciafaba L. Minor) yield in Meknes region, Morocco.
}

\author{
Abdellatif Boutagayout ${ }^{1,2 *}$, Laila Nassiri $^{1}$, El Houssine Bouiamrine ${ }^{1}$ and Saadia Belmalha $^{2}$ \\ ${ }^{1}$ The Environment and Soil Microbiology Unit, Faculty of Sciences-Moulay Ismail University, \\ B.P.11201 Zitoune, Meknes 50000, Morocco. \\ ${ }^{2}$ Department of Plant and Environment Protection, Ecole Nationale d'Agriculture de Meknès, Route \\ Haj Kaddour, BP S/40 - 50000 Meknès, Morocco.
}

\begin{abstract}
In order to protect human health and the environment and to prevent the occurrence of weed ecotypes, global efforts are being made to reduce the world's high dependency on synthetic herbicides for weed control. In this perspective, a field experiment was conducted during 2018/2019 season at the educational farm of the National School of Agriculture of Meknes (Morocco) to evaluate mulch effect of black plastic, oat straw and sycamore leaves on both faba bean and weed growth at flowering and harvest stage. The experiment was performed according to a randomized complete block design (RCBD) repeated four times. The results showed that the highest weeds infestation was recorded in weedy check (Control). Sycamore leaves, oat straw and black plastic mulches have significantly reduced weeds density and biomass, thus provided efficiency by $84.8,80.6$ and $86.8 \%$ respectively. In addition, the oat straw, black plastic, and sycamore leaves have improved faba bean yield by 42 , 52.9 , and $43 \%$ respectively. In conclusion, mulching practice can be a promising alternative of weed management for faba bean crop in Meknes region.
\end{abstract}

\section{Introduction}

Faba bean (Viciafaba L.) is one of the most important cultivated species of the fabaceae family [1]. Due to its economic, environmental and agro-ecological performances, faba bean contributes to the sustainability of farming systems. The varieties of Viciafaba L. have considerable importance as a low-cost, and protein-rich (20-25\% seeds) food, which makes it the main source of protein in Africa [2]. Like all legumes, faba beans have the ability to fix atmospheric nitrogen by a symbiotic relationship with bacteria, particularly the genus of rhizobium [3], thus, increases soil fertility and the productivity of agricultural lands. Unfortunately, this craze is waning over time [4]. Until the late 1970s, Morocco was the world's second largest exporter of food legumes, mainly faba beans. Eventually, Morocco imported about $9 \%$ of annual needs to offset its production [5].

Abiotic and biotic factors are major constraints that limit yield and cause instability of faba bean [2], in addition, faba bean crop is very sensitive to weed competition, thus weed

\footnotetext{
*Correspondingauthor:abdellatif.boutagayout@edu.uca.ac.ma
} 
management is very important for crop production [6]. For example, the yield of a bean weed infested crop is reduced by up to $80 \%$ [7]. Regarding of the harmful effects of herbicides use on humans and environment [8], a reasonable and careful attitude must be envisaged to limit or even stop the use of agrochemical products [9].

In this context, several methods provide information on agroecological practices such as mulching that can lead to sustainable weed management [10]. In organic farming, mulching is very useful as one of the strategies for integrated weed management [11], by providing a barrier to light, heat or moisture exchange [12]. It reduces evaporation, preserves moisture, and regulates structure and temperature [13]. On the other hand, mulching practice has several advantages, such as improving soil structure and quality by increasing infiltration and water retention capacity, and providing a refuge for many insects and earthworms [9]. Moreover, it facilitates root penetration and development, and thus nutrient uptake from deeper soil layers [14], also it can reduce erosion [15].

The present study was conducted in an experiment field to evaluate the effect of organic and inorganic mulch on weeds density and biomass, as well as on faba bean yield components.

\section{Material and methods}

\subsection{Site and Field trial}

Faba beans (Viciafaba L. var. minor) (local cultivar) were sown in 2018-2019 season in one of the fields of National School of Agriculture of Meknes, Morocco (33 $53^{\circ} 3.322^{\prime \prime} \mathrm{N} 5^{\circ}$ $\left.28^{\prime} 18.887^{\prime \prime} \mathrm{W}\right)$. The study area has a Mediterranean climate; winters are cool, and rainy, and the summers are hot and dry. Laboratory analysis showed that the soil texture is silty clay with $1.5 \%$ of organic matter. Soil $\mathrm{pH}$ is 8.78 , the total nutrients content in the soil are $13.0 \mathrm{ppm}$ of phosphorus, and $26.8 \mathrm{ppm}$ of potassium. The faba bean seeds were sown using a seed machine attached to a tractor set at a depth of 5-6 cm, a distance of $50 \mathrm{~cm}$ between rows, and at a density of $100 \mathrm{Kg} / \mathrm{ha}$. The faba bean crop was grown without any chemical fertilizer input. Irrigation and other agronomic practices were done properly and uniformly to grow a successful crop. The growing season for faba bean is from mid-December to midJune.

\subsection{Treatments and experimental design}

Three treatments were tested; black polyethylene (black plastic), oat straw (4t/ha) and plane tree leaves (Sycamore leaves) $(4 \mathrm{t} / \mathrm{ha}$ ) were applied between the rows immediately after faba bean emergence to compare these treatments with weedy check (Untreated). The experiment was laid out in a randomized complete block design, with four replications.

\subsection{Data collection}

Weeds density and biomass were determined by using square of $0.5 \mathrm{~m} \times 0.5 \mathrm{~m}$, randomly launched in each plot at the flowering and maturity stage. The dry weight of weeds and crops was determined after oven drying at $105{ }^{\circ} \mathrm{C}$ until complete drying and constant weight [16]. The average weed biomass for each treatment was calculated and expressed in $\mathrm{g} / \mathrm{m}^{2}$. Also, weed control efficiency (WCE) was assessed based on percentage reduction in dry weed biomass [4], the WCE efficiency was calculated as following: 
W. C.E $(\%)=\frac{\text { Weed dry matter in weedy check }- \text { weed dry matter in treated plot }}{\text { Weed dry matter in weedy check }} \times 100$

At maturity stage, the plant height, the number of pods, the number of seeds, the number of branches, the seed yield (tons/ha) and the 100 seed weight in gram were recorded from 10 plants in each net plot.

\subsection{Statistical analysis}

The results were subjected to analysis of variance (ANOVA) ; using statistical software IBM SPSS Statistics 21 to assess mulching practices effects on the considered variables. The normality of the data was evaluated through the Tukey test. Unless otherwise stated, the significance level was $\mathrm{p} \leq 0.05$.

\section{Results and discussion}

\subsection{Weed flora associated with faba bean}

Table 1. Common weeds associated with faba bean crop during the experimentation

\begin{tabular}{|c|c|c|}
\hline Species & Common name & Family \\
\hline PolygonumavicularL. & Prostrateknotweed & Polygonaceae \\
\hline Glebioniscoronaria $\mathrm{L}$. & Crown daisy & Asteraceae \\
\hline Calendula arvensis $\mathrm{L}$. & Field marigold & Asteraceae \\
\hline Sonchusoleraceus $\mathrm{L}$. & Common sowthistle & Asteraceae \\
\hline Helminthiaechioides $\mathrm{L}$. & Bristlyoxtongue & Asteraceae \\
\hline Fumariaparviflora Lam. & Fineleaffumitory & Papaveraceae \\
\hline Papaver rhoeas $\mathrm{L}$. & Common poppy & Papaveraceae \\
\hline Chenopodium album L. & Fat hen & Amaranthaceae \\
\hline Galium aparine $\mathrm{L}$. & Cleavers & Rubiaceae \\
\hline Biforatesticulata $\mathrm{L}$. & MundaneEuropean bishop & Apiaceae \\
\hline Lamium amplexicaule L. & Henbitdead-nettle & Lamiaceae \\
\hline Coronillascorpioides $(\mathrm{L}$.$) Koch$ & Yellow crownvetch & Fabaceae \\
\hline Vicia sativa L. & Common vetch & Fabaceae \\
\hline Medicagopolymorpha $\mathrm{L}$. & Burclover & Fabaceae \\
\hline Sinapisarvensis $\mathrm{L}$. & Wild mustard & Brassicaceae \\
\hline VaccariahispanicaMill. & Cowsoapwort & Caryophyllaceae \\
\hline CichoriumintybusL. & Common chicory & Asteraceae \\
\hline DiplotaxisassurgensThell. & Mursenaper & Brassicaceae \\
\hline Bromusstirilis L. & Barren brome & Poaceae \\
\hline Phalaris minor Retz. & Littleseedcanarygrass & Poaceae \\
\hline
\end{tabular}

The total weed species identified in the floristic surveys carried out at the experimental field as well as the common names and botanical families of each species are revealed (Table 1). The total weed flora identified was very diverse; with 20 species distributed over 13 families. The most dominant weed species found in the faba bean field were Polygonumavicular, Glebioniscoronaria, Vaccariahispanica, Papaver rhoeas and 
Fumariaparviflora etc. broad-leaved weeds (dicotyledonous) are the most dominant, while Grasses weeds (monocots) are represented only by two species (Bromusstirilis and Phalaris minor).

Finally, the asteraceae family is the most frequent in the study field with 4 species followed by the fabaceae ( 3 species).

\subsection{Weed density}

Organic and inorganic mulches provide better management of the weed community compared to the control (Table 2), although the use of plastic mulch showed no significant difference compared to the use of oat straw and plane tree leaves, a slight advantage was observed with plastic mulch. This can be explained by the inhibitory effect of black plastic against weed germination and by exerting physical pressure on weeds [17]. However, another study was carried out in Lithuania by Jodaugienè $e$ al. [18] to evaluate the effect of organic mulch (wheat straw, peat, wood chips...) on weeds in common bean crop (Phaseolus vulgaris L.), showed that organic mulches were very effective in reducing weed germination and emergence.

For their part, Döringet al. [19] found that straw mulch did not affect weed numbers, coverage, and above-ground biomass; this may have been due to the relatively modest quantities of straw applied or to its infestation by weed seeds.

Table 2.Effects of oatstraw, plastic, and plane treeleavemulches on weeddensity at the flowering and maturity stage

\begin{tabular}{|c|c|c|c|c|}
\hline $\begin{array}{l}\text { Treatemts Stage } \\
\text { growth }\end{array}$ & $\begin{array}{c}\text { weedy } \\
\text { check }\end{array}$ & Oatstraw & Black plastic & $\begin{array}{c}\text { Plane } \\
\text { treeleaves }\end{array}$ \\
\hline Flowering stage & $468.5 \mathrm{a}$ & $89.5 \mathrm{~b}$ & $65 \mathrm{~b}$ & $83.5 \mathrm{~b}$ \\
\hline Maturity stage & $562.5 \mathrm{a}$ & $92.5 \mathrm{~b}$ & $75.5 \mathrm{~b}$ & $85.5 \mathrm{~b}$ \\
\hline
\end{tabular}

In the row, the mean values followed by the samelower case letters are not significantlydifferent.

On the other hand, a study carried out on an organic field faba bean crop [20], revealed that oat straw mulch ( 4 or $6 \mathrm{t} / \mathrm{ha}$ ) resulted in effective weed control, especially photosensitive weeds such as Chenopodium album L. and Matricaria spp.

\subsection{Weed Biomass}

Table 3 shows that the effect of mulching on biomass is very important. The different types of mulch used, especially black plastic, increases faba bean biomass. The plastic mulch improves the biomass of faba bean by about $57 \%$ compared to the control, while the organic mulches each increase it by about $49 \%$.

Table 3.Effects of oatstraw, black plastic, and plane treeleavesmulches on weed and fababeanbiomass at the flowering and maturity stage

\begin{tabular}{|c|c|c|c|c|c|}
\multicolumn{1}{c|}{} & \multicolumn{1}{c|}{ at the flowering and maturity stage } & $\begin{array}{c}\text { Plane } \\
\text { treeleaves }\end{array}$ \\
\cline { 2 - 6 } \multicolumn{1}{c|}{} & $\begin{array}{l}\text { Treatemts } \\
\text { Stage growth }\end{array}$ & $\begin{array}{c}\text { weedy } \\
\text { check }\end{array}$ & Oatstraw & Black plastic & \\
\hline \multirow{2}{*}{$\begin{array}{c}\text { Weedsbiomass } \\
\left(\mathrm{g} / \mathrm{m}^{2}\right)\end{array}$} & Flowering stage & $453.89 \mathrm{a}$ & $65.81 \mathrm{~b}$ & $58.33 \mathrm{~b}$ & $60.54 \mathrm{~b}$ \\
\cline { 2 - 6 } & Maturity stage & $586.40 \mathrm{a}$ & $142.18 \mathrm{~b}$ & $78.72 \mathrm{~b}$ & $99.93 \mathrm{~b}$ \\
\hline $\begin{array}{c}\text { Fababeanbiomass } \\
\left(\mathrm{g} / \mathrm{m}^{2}\right)\end{array}$ & Flowering stage & $75.57 \mathrm{a}$ & $160,92 \mathrm{~b}$ & $181.23 \mathrm{~b}$ & $150.54 \mathrm{ab}$ \\
\cline { 2 - 6 } & Maturity stage & $94.72 \mathrm{a}$ & $171.99 \mathrm{ab}$ & $213.87 \mathrm{~b}$ & $183.75 \mathrm{~b}$ \\
\hline
\end{tabular}

In the row, the mean values followed by the samelowercaseletters are not significantlydifferent.

Concerning weeds, their biomass varies very significantly compared to the control, and lower extent between the different types of mulch; the maximum value of weed biomass is 
recorded in the second survey of the control (without mulch) with $586.45 \mathrm{~g} / \mathrm{m}^{2}$. However, the lowest weed biomass is observed in mulch treatments, especially plastic-based mulch, at the flowering stage $\left(58.33 \mathrm{~g} / \mathrm{m}^{2}\right)$. Similarly, a study showed that the use of plastic mulch (black or white), wheat or rapeseed necessarily reduced weed biomass compared to the control, moreover, there was no significant difference between the treatments used [21].

\subsection{Weed Control efficiency (WCE)}

Weed control effectiveness against weeds through the use of mulch ranges from $75.7 \%$ to $87.1 \%$ (Table 4 ); the maximum value is obtained with plastic mulch, in the first survey $(87.1 \%)$, followed by the application of sycamore leaves $(86.7 \%)$, in the same period. In general, this control efficiency is greater during the flowering stage than during crop maturity. On average, mulching with black plastic mulch had the highest value $(86.8 \%)$, followed by plane tree leaf mulch $(84.8 \%)$ and oat straw $(80.6 \%)$, respectively. In the same way, Kouelo et al. [22] showed that mulches provide $80 \%$ of weed control efficiency.

Azadbakht et al. [21] found that wheat and rapeseed mulch treatments can reduce weed biomass compared to controls at rates of $83 \%$ and $81 \%$, respectively. Similarly, Mehmood et al. [23] reported similar results that application of black plastic mulch showed a maximum reduction in weed density, fresh and dry weed biomass and suggested that organic mulches such as dry eucalyptus leaves and wheat or rice straw could be used for effective weed control in cornfields.

Table 4. Weed Control efficiency (WCE) of mulches against weeds in faba bean field

\begin{tabular}{|c|c|c|c|c|}
\cline { 2 - 5 } \multicolumn{1}{c|}{} & Weedy check & Oatstraw & Black plastic & Sycamoreleaves \\
\hline Flower stage (\%) & - & 85.5 & 87.1 & 86.7 \\
\hline Maturity stage (\%) & - & 75.7 & 86.6 & 83 \\
\hline Average (\%) & - & 80.6 & 86.8 & 84.8 \\
\hline
\end{tabular}




\subsection{Yield and yield components of faba bean}

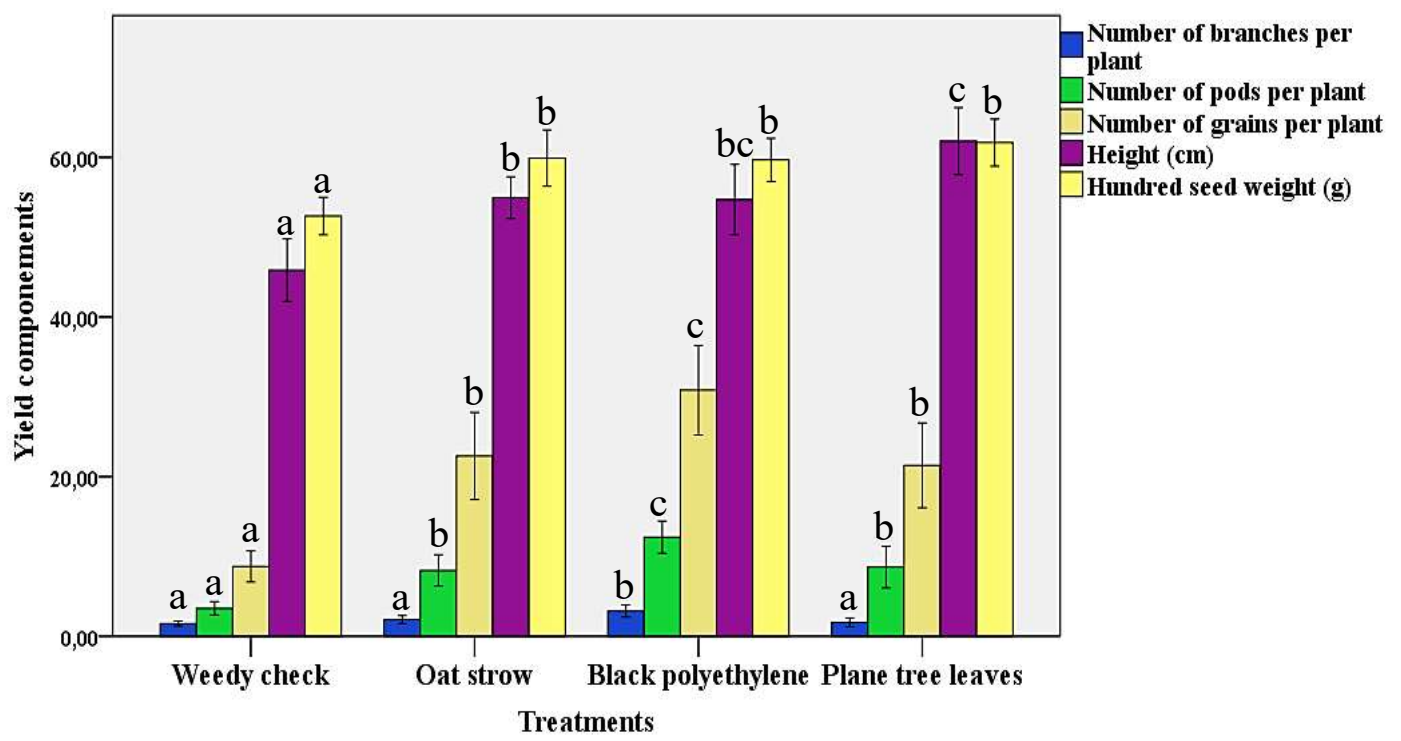

Fig.1.Effect of oatstraw, blackpolyethylene, and plane treeleavesmulches on fababeanyield components

The influence of mulch tested on the yield components of faba bean is illustrated in Figure 1. Average yields are significantly higher than the control. Indeed, the best yield is obtained with plastic mulch. This yield gain is more marked on the number of seeds, pods and branches, while for plant height the plane tree leaves mulch that ensures better faba bean growth (Figure 1). Similarly, the hundred seed weight is also increased compared to weedy check, but remains the same between the different types of mulch. Therefore, an improvement in yield per unit area of approximately $42,52.9$ and $43 \%$ is achieved with oat straw, black plastic, and plane tree leaves, respectively (Figure 2).

Tukey's test indicates that there is no significant difference between the values of the yield components obtained by oat straw and plane tree leaf mulches; indeed, the organic mulches provided intermediate yields between the control and black plastic, reflecting the mulches ability to control weeds and prevent their growth and propagation [24].

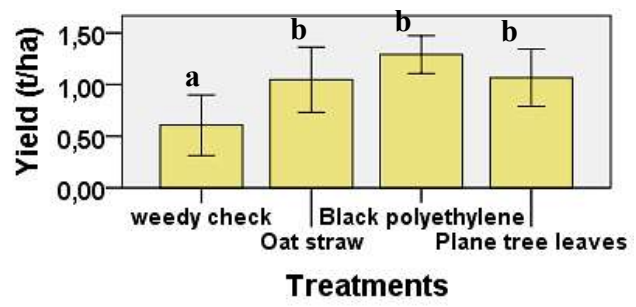

Fig. 2.Fababeanyield (tons per hectare)

Another study showed that mulching significantly improved grain yield, as well as crown diameter, leaf area index, and growth rate of maize $(\mathrm{p}<0.0001)$ [22].Mesfineet al. [24] also obtained an increase in sorghum grain yield.

Mulching can affect yield in many ways, including increasing soil moisture and water use efficiency in arid and semi-arid conditions [24-25], as well as increasing nitrogen, carbon and phosphorus levels [22]. 
For their part, Duppong et al.[26] reported that the height of a medicinal plant was significantly higher when oat straw was applied than in other treatments (flax and wool straw) and even higher than the positive control (manual weeding).

It should also be noted that plant residues not only affect the soil, but can also affect the germination, survival, growth, and competitiveness of weeds and crops. However, the use of mulch can be expensive due to labor costs and other costs associated with mulch preparation. Still, regardless the costs, it can be noted that environmentally friendly methods such as the application of plant residues allows long-term environmental durability[21].

\section{Conclusion}

The negative impacts of herbicides on humans, animals, and environment has attracted the attention of researchers to find new environmentally-friendly methods for weed control. From the data presented, we conclude that the mulch practice could be one of the possible strategies to reduce the use of herbicides in the faba bean crop, mainly by reducing density and biomass of weed species. Indeed, the weed control efficiency of straw mulch, black plastic, and plane tree leaves has been around $80.6,86.8,84.8 \%$ respectively, which allow an improvement in faba bean yield components (height, number of grains, pods, and branches...), therefore they allowed an increase in faba bean yield (tons/ha) by 42, 52.9 and $43 \%$ compared to the weedy check.

\section{References}

1. H. Labuda, Flowering and characteristics of useful traits of some faba bean (Viciafaba L. var.major Harz) cultivars and breeding lines,ActaAgrobot, 65 (4) (2012)

2. S. G. Kumari\& K. M. Makkouk, Virus diseases of faba bean (Viciafaba L.) in Asia and Africa, Plant Viruses, 1 (2007)

3. P. Ruisi, D. Giambalvo, G. Di Miceli, A.S. Frenda, S. Saia \&G. Amato, Tillage effects on yield and nitrogen fixation of legumes in Mediterranean conditions, Agron.104, 14591466 (2012)

4. B. Hajjaj, R.Mrabet, M. Bouhache, A. Taleb, \&A. DOUAIK, Rev. Mar. Sci. Agron. 4(2016)

5. M. Fouad, N. Mohammed, H. Aladdin, A. Ahmed, Z. Xuxiao, B.Shiying, \&Y. Tao, Elsevier, 113-136 (2013)

6. M. Bouhache, \&S. Benmansour,AMPP, 6, 51-62 (2014)

7. M.G. Dawood, Weed management, folic acid and seaweed extract effects on Faba bean plants and associated weeds under sandy soil conditions, Int. J. Agric. Eng.,19(2018)

8. E. Pannacci, F.Tei, \& M. Guiducci,Mechanical weed control in organic winter wheat,Ital. J. Agron.,12(2017)

9. J. Pousset,Ed.Agridécisions,ISBN291219914X, Paris, 704 (2003)

10. B. Melander, I.A. Rasmussen, \& P. Bàrberi,Integrating physical and cultural methods of weed control-examples from European research, Weed Sci., 53, 369-381 (2005)

11. A. Matković, D. Božić, V. Filipović, D.Radanović, S. Vrbničanin, \&T. MarkovićMulching as a physical weed control method applicable in medicinal plants cultivations,Lekovitesirovine, 35 (2015) 
12. A. M. El Mahi,Chemical Weed Control InFaba Bean (ViciaFaba L.) Using Two Foliar Applied Herbicides,Master thesis, University of Khartoum, 117 (2015)

13. M.A. Kader, M. Senge, Mojid M.A., \& K. Ito, Recent advances in mulching materials and methods for modifying soil environment, Soil Tillage Res,168 (2017)

14. P. Ranjan, G.T. Patle, M.Prem, \&K.R. Solanke,Curr. Agric. Res. J., 5(2017)

15. S.G. Telkar, A.K. Singh, K. Kant, S.P.S. Solanki \& D. Kumar, Biomolecule Reports Ed. 4 (2017)

16. R. Benniou, K. Zabi, ...\& H.Belguet, Revue Agriculture Ed.,1, 230-239 (2016)

17. D. C. Chang, J.H. Cho, Y.I. Jin, J.S. Im, C.G. Cheon, S.J. Kim, \& H.S. Yu, Mulch and planting depth influence potato canopy development, underground morphology, and tuber yield,Field Crops Res., 197 (2016)

18. D. Jodaugienè, R. Pupalienė, M. Urbonienė, V. Pranckietis,\& I. Pranckietienè, The impact of different types of organic mulches on weed emergence,Agron. Res., 4(2006)

19. T. F. Döring, M. Brandt, J. Heß, M. R. Finckh, \& H. Saucke,Effects of straw mulch on soil nitrate dynamics, weeds, yield and soil erosion in organically grown potatoes, Field Crops Res., 94 (2005)

20. L. F. P. Massucati\&U. Kopke,Effect of straw mulch residues of previous crop oats on the weed population in direct seeded faba bean in Organic Farming,inProceedings 26th German Conference on Weed Biology and Weed Control,Braunschweig, Germany, 11-13 March, 2014(2014)

21. A. Azadbakht, M. T. Alebrahim, \& A. Ghavidel, The effect of chemical and nonchemical control methods on weeds in potato (Solanumtuberosum L.) cultivation in ardabil province, Iran,APPL ECOL ENV RES Ed.,15(2017)

22. A. F. Kouelo, P. Houngnandan, A. Azontonde, M. Benmansour, J. Bekou, \& T.AkploAgron. Afr., 29, 65-78 (2017)

23.T. Mehmood, S. Khan, A. Qayyum, A.R. Gurmani, W. Ahmed, M. Liaquat\& A.FaridEvaluation of Organic and Inorganic Mulching as an Integrated Weed Management Strategy in Maize Under Rainfed Conditions, Planta Daninha, 36, 13 (2018)

24. T. Mesfine, G. Abebe, \& A. R.M. Al-Tawaha, Effect of reduced tillage and crop residue ground cover on yield and water use efficiency of sorghum (Sorghum bicolor (L.) Moench) under semiarid conditions of Ethiopia,World J. Agric. Res., 1(2005)

25. S. Chandra, R. D. Singh, V. K. Bhatnagar\& J. K. Bisht, Effect of mulch and irrigation on tuber size, canopy temperature, water use and yield of potato (Solonumtuberosum), indian j Agron, 47, 443-448 (2002)

26. L. M. Duppong, K. Delate, M.Liebman, R.Horton, F. Romero, G. Kraus \& P. K. Chowdbury,CROP SCI, 44(2004) 